\title{
Segmentation Comparing Eggs Watermarking Image and Original Image
}

\author{
Anton Yudhana ${ }^{1}$, Sunardi ${ }^{2}$, Shoffan Saifullah ${ }^{{ }^{3}}$ \\ ${ }^{1,2}$ Department of Electrical Engineering, Universitas Ahmad Dahlan, Yogyakarta, Indonesia \\ ${ }^{3}$ Master of Informatics Engineering Universitas Ahmad Dahlan, Yogyakarta, Indonesia \\ JI. Prof. Dr. Soepomo, S.H. Janturan Yogyakarta, 55164, Indonesia \\ ${ }^{*}$ Corresponding author, e-mail: eyudhana@mti.uad.ac.id ${ }^{1}$, sunardi@mti.uad.ac.id ${ }^{2}$, \\ shoffan_s@yahoo.com ${ }^{3}$
}

\begin{abstract}
The research used watermarking techniques to obtain the image originality. The aims of the research were to identify small area in eggs properly and compared preprocessing, the methods, and the results of image processing. The study has been improved from the previous papers by combined all methods and analysis was obtained. This study was conducted by using centroid and the bounding box for determining the object and the small area of chicken eggs. The segmentation method was used to compare the original image and the watermarked image. Image processing using image data that are subject watermark to maintain the authenticity of the images used in the study will the impact in delivering the desired results. In the identification of chicken eggs using watermark image using several methods are expected to provide results as desired. Segmentation also deployed to process the Image and counted the objects. The results showed that the process of segmentation and objects counting determined that the original image and watermarked image had the same value and recognized eggs. Identification had determined percentage of $100 \%$ for all the samples.
\end{abstract}

Keywords: watermarking, centroid and bounding box, segmentation, counting object

\section{Introduction}

Originals image has an enormous influence in the ownership of copyright. Image is capable of electronic information disseminated quickly. One of the intellectual work that is protected is in the form of digital goods, such is the image [1-2]. During this time doubling on digital products is conducted freely and unimpeded [2], so it needs to be assured of the authenticity of the picture.

Identification of chicken egg with a chicken egg image processing using segmentation [3-6] based on digital imagery and thermal imagery. Utilization of thermal cameras [3], [6] is used in the process of image acquisition. Segmentation with eggs image processing is done by comparing the digital image acquisition to image thermal [3], and image compression results with the original image [4], as well as image cropping the original image results [5]. So the segmentation is able to identify chicken eggs.

The first-order statistical method [7-8] based on the cleanliness of the chicken egg shell to extract characteristic on second-order statistics, is able to classify eggs with K-Nearest Neighbor method (88.89\%) [7]. Physical shape and color of the egg in an egg identification image processing performed by several methods such as changing the value of gray, image contrast enhancement, filtering with a Gaussian filter, histogram equalization, Otsu thresholding segmentation, and segmentation. This method is able to distinguish eggs on the difference in value statistics [8]. Image acquisition with then performed chicken egg size classification and weighting with segmentation method. Based on data from 36 samples of chicken eggs were able to classify all the data, but weighting only $42 \%$ were able to predict the corresponding weights of all the samples [9].

Identification of egg fertility detection is based on the content of the embryo [10-13] is able to do. Thresholding method (score of 50) were able to identify embryonated eggs, but of broken eggs failure of $8.3 \%$ [10]. Identification of chicken eggs with the acquisition of a thermal imaging camera [11-12]. Thermal Imaging is a technique to capture the conversion of objects 
into images visually heat of infrared energy (invisible) emitted by the object [14]. With the curve method of cold, cold regions, development, oval shape and morphology of the eggs, as well as the extraction of eggs with Region of Interest (ROI) [11], [13] is able to detect the egg is not fertilized (4 days) amounted to $89.6 \%$, and the embryo eggs (16 days) amounted to $96.3 \%$ [11].

The process of identification and screening egg fertility method Sobel operator, fuzzy theory and co-occurrence matrix capable of running with $96 \%$ accuracy and detection speed of 2-3 seconds [12]. Hyperspectral imaging can also be used in the detection of fertility eggs. Kmeans in the classification of the egg (the incubation process), on day $1(65.29 \%)$, day 2 $(61.18 \%)$, day $3(72.94 \%)$, and day $4(84.12 \%)$, with the conclusion that embryonic development is difficult to detect during the first 2 days in the incubator eggs [13].

Connected component analysis method for segmentation process can distinguish between chicken eggs and quail eggs and can count the number of eggs [15]. The introduction of an egg with the centroid method classifier and HSV (Hue, Saturation and Value) shows the difference eggs. Duck egg that characterizes the average hue between 0.089 to 0.094 and an average saturation of between 0.12 to 0.32 , while the domestic chicken eggs provide characteristics that the average hue between 0.033 to 0.053 and an average saturation between 0.52 to 0.62 , while chicken eggs provide characteristics that the average hue between 0.061 to 0.068 and an average saturation of between 0.21 to 0.25 [16].

The study ever conducted into references to the use of methods, analysis, results were given. So this research provides a different contribution to the studies that have been there. The research is a comparative analysis of original image with the image that is subjected to the watermark in the segmentation process for identifying eggs and counting the number of eggs detected image processing using image data subjected to the watermark to maintain the authenticity of the images used in the study would give effect to give the desired results. Identification of chicken eggs using a few methods of watermarking is expected to deliver the result desired. Image processing to be used premises using segmentation method and counting objects.

\section{Materials and Methods}

Based on Figure 1 shows the method used mainly in the identification and calculation object eggs. The concept is important in image processing from preprocessing and the main function of segmentation and calculation object using region props and labeling.

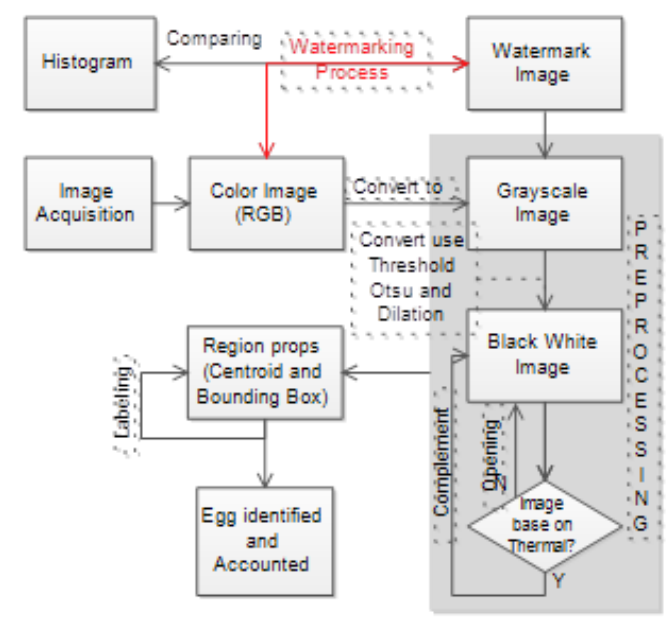

Figure 1. The method of process for identity eggs

\subsection{Image Processing}

The image is an image, likeness or imitation of an object. The image can be a photo, a video signal (picture on TV) or digital image that can be directly stored in the storage media. Images that can be processed by a computer called a digital image. Each image can be 
obtained by image acquisition, which is a process that is performed to obtain a digital image to image. Imaging is a way to change the image looks (photos, drawings, sculptures, etc.) [17].

The process is done to improve the image preprocessing to improve image quality by setting the contrast and brightness, eliminate noise [18], image restoration, image transformation, and determine which parts of the image that will be observed. Preprocessing is conducted by changing the original image (color/RGB) into a grayscale image. The intensity values for each pixel in the image is a single value where the gray level intensity value is in the interval 0-255, while in color images need three intensity values which are at intervals of 0-255 for each pixel. Getting closer to the value of 255, then the degree of gray will be even brighter. Basically, this process is done with leveling the pixel values of the three RGB values into one value [17].

Histogram equalization is a statistical probability distribution of each gray level (grayscale) in digital image [19-20]. Methods used for smoothing the histogram of grayscale images, so the images are grouped into levels of intensity values of pixels of different colors. The 8-bit grayscale image has 256 different levels of intensity value. The histogram is displayed in a distributed graph for each of the 256 level of the pixel value.

Operation opening and dilation19 is part of the process morphology. Morphology is an image processing technique that is based on the shape of a segment (the image area). Dilation is used to enlarge the size of the segment around the object, and Opening used to reduce the size of the image, then just do the dilation process and serves to smooth the object boundaries, smoothes the object and eliminate the noise. So with morphology capable of distinguishing between objects with different backgrounds (e.g. Text rather than text [21] on the image so as to provide better text extraction [21-22]).

\subsection{Watermarking}

One way to protect the copyright of multimedia is to insert information in the multimedia data with watermarking technique. Information to be inserted into multimedia data called a watermark, and the watermark can be considered as digital prints (digital signature) from the legal owner of the multimedia product. In other words, the watermark inserted into a label copyright of their owners. Giving signatures with watermarking technique is performed such that the embedded information is not damaging the digital data are protected. So, the person who opened the multimedia product that has been inserted watermarks do not realize that in the multimedia data contained proprietary label maker.

Mechanical watermarking is the process of adding an identification code permanently into digital data. The identification code can be text, images, sounds, or video. In addition to not damage the digital data product to be protected, the inserted code should have a resistance (robustness) on a variety of advanced processing such as conversion, geometric transformations, compression, encryption, and so on. The nature of the data means the robustness of the watermark is not cleared by the advanced processing [17]. Watermarking method No 2 is the spatial domain (time, position) directly into the pixel image (eg LSB) and frequency domain (eg Discrete Fourier Transform, Discrete Cosine Transform, Singular Value decomposition, Discrete Wavelet Transform).

\subsection{Segmentation and Counting Object}

Segmentation is a method used to partition/dividing the image into several constituent parts that have important information. In this study used to detect objects by separating object with the background (background) [17]. Segmentation in this study uses two methods, thresholding and labeling. The thresholding segmentation process of a grayscale image was deployed to convert from a grayscale image into a binary image. Binarization process requires a threshold value $(T)$. Otsu threshold algorithm is used to segment gray digital image into a digital image of black (foreground) and white (background). Otsu thresholding histogram gives the distribution of intensity value for each pixel in the image in one dimension. The histogram function in grouping the pixels in the image is based on a threshold value. So as to obtain maximum results, the threshold value must be able to separate the classes so that the pixel intensity values between different classes.

Region props are used to assist in the determination process of determining the value of the centroid and the bounding box area. The centroid is used to determine the mean number of 
detected eggs as image object that has a value based on the $x$ and $y$-axis. The bounding box is the method was used to detect object and tagged the square marking unidentified objects [23].

\section{Results and Analysis}

Figure 2 shows the images used to compare the process of identifying the eggs of the original image (digital image shown in Figure 2(a), thermal image shown in Figure 2(b), and the watermarked image shown in Figure 2(c).

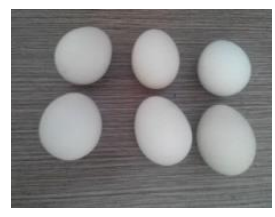

(a)

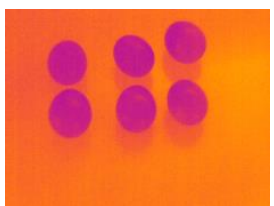

(b)

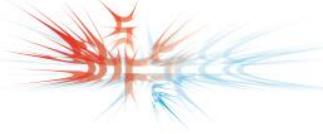

(c)

Figure 2. Image of (a) Original (b) Thermal (c) Watermark

Comparison grayscale image with the image watermarking process is carried out by using Figure 2. (c), of the digital image (Figure 2 (a)), and thermal image (Figure 2 (b)) using the methods of insertion of watermark image so that the image obtained as shown in Table 1.

\begin{tabular}{|c|c|c|c|c|}
\hline \multirow[t]{2}{*}{ Method } & $\begin{array}{l}\text { Grayscale } \\
\text { Image }\end{array}$ & $\begin{array}{c}\text { Image } \\
\text { Watermarking }\end{array}$ & & \\
\hline & Digital & Thermal & Digital & Thermal \\
\hline $\begin{array}{l}\text { Domain } \\
\text { Spatial }\end{array}$ & & & & \\
\hline FFT & & & & 00 \\
\hline DCT & & & & 00 \\
\hline DWT & & & & 000 \\
\hline SVD & & 0 & & 00 \\
\hline
\end{tabular}

From the original image with a size greater good of digital imagery and thermal imagery, using watermarking process in this research is necessary to resize the size. Of the several methods used to process the obtained size of the image watermarking shown in Table 2. 
Table 2. Image Size

\begin{tabular}{ccc}
\hline \multirow{2}{*}{ Method } & \multicolumn{2}{c}{ Size of all images } \\
\cline { 2 - 3 } & disk & dimensions \\
\hline Domain Spatial & $88.9 \mathrm{~KB}$ & $300 \times 300$ (pixels) \\
FFT & $88.9 \mathrm{~KB}$ & $300 \times 300$ (pixels) \\
DCT & $88.9 \mathrm{~KB}$ & $300 \times 300$ (pixels) \\
DWT & $157 \mathrm{~KB}$ & $400 \times 400$ (pixels) \\
SVD & $40.1 \mathrm{~KB}$ & $200 \times 200$ (pixels) \\
\hline
\end{tabular}

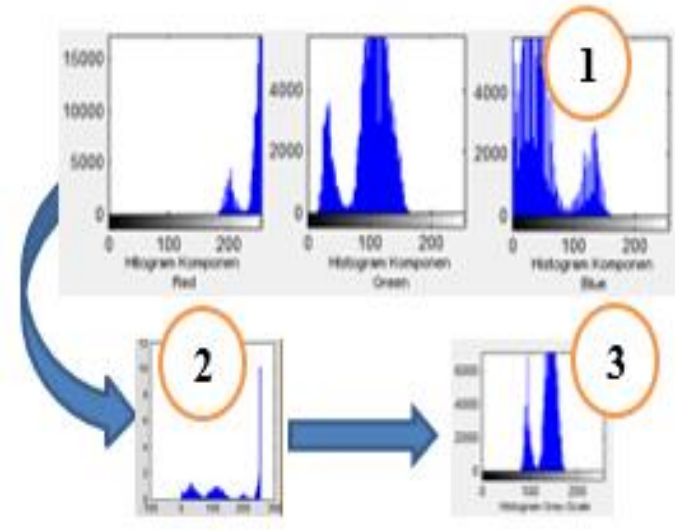

(a)

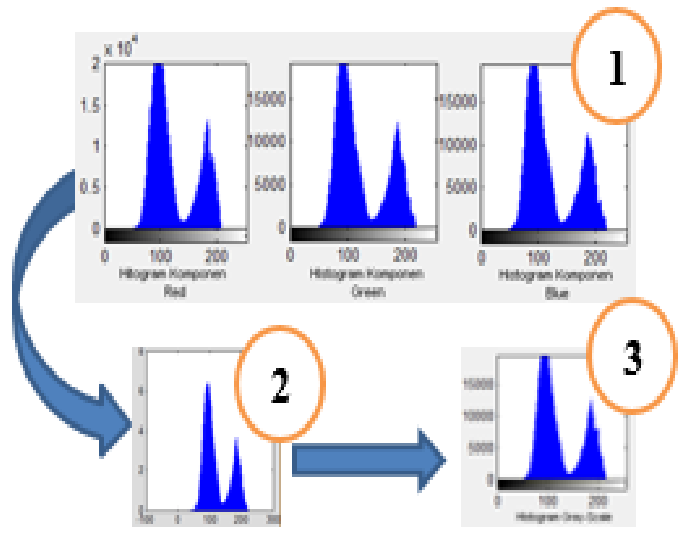

(b)

Figure 3. Histogram of (a) Digital image and (b) Thermal image

Digital image (Figure 2) and the thermal image (Figure 3) obtained by the image histogram with each color produced (number 1) and the merger of each color histogram (Red, Green, Blue) in order to obtain the image number 2. Next to get a histogram smoothing the color image into a grayscale image needs to be changed so that give histogram which denser (number 3).

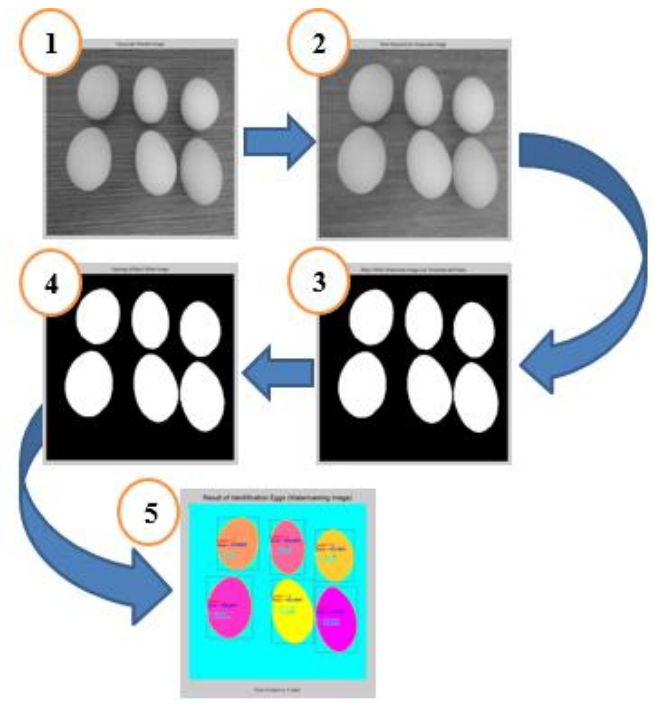

Figure 4. Eggs image identification from research method (Figure 1) 


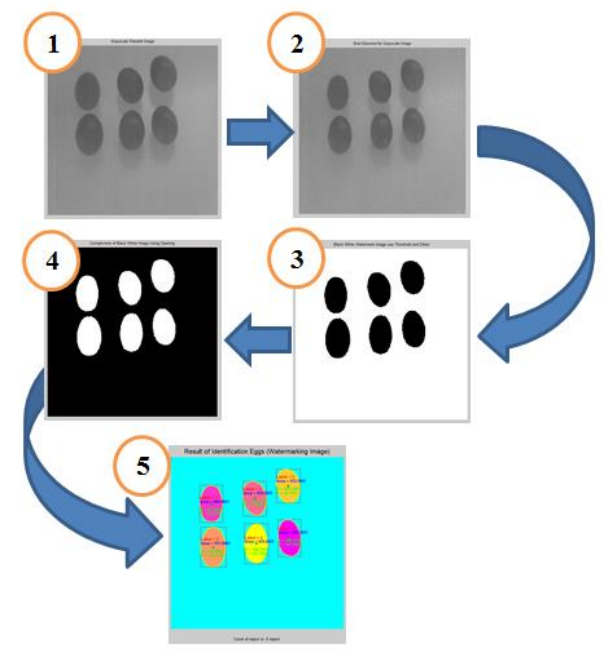

Figure 5. Eggs image identification from research method (Figure 1)

The results of Research Methods of implementation (Figure 1) is shown in Figure 4 and Figure 5. The processing of the initial image is to change a color image to grayscale (number 1). Then converted into a black and white image using Otsu thresholding and dilation process. If the thermal image will be the complement of the image in black and white, but if the digital image will perform an opening. After which it will be done using the region segmentation process with props (centroid and the bounding box), and labeling. The results will do the calculation process objects. Based on Figure 4 and Figure 5 and obtained the same results for the original image and watermark image of the same values.

\section{Conclusion}

The research showed the results that the process of segmentation and objects counting between the original image and the watermarked image had the same value and success to recognize and identify objects of eggs. Identification value of $100 \%$ for all the results.

\section{References}

[1] M Averkiou. Digital Imaging. E-books [Online]. [Access: December 10, 2016]. https://www.cl.cam.ac.uk/teaching/0910/R08/work/essay-ma485-watermarking.pdf.

[2] Rinaldi Munir. Pengolahan Citra Digital. E-book [Online]. [Access: December 10, 2016] http://informatika.stei.itb.ac.id/ rinaldi.munir/ Buku/Pengolahan\%20Citra\%20Digital/E-book.htm.

[3] Sunardi, A Yudhana, S Saifullah. Identity Analysis of Egg Based on Digital and Thermal Imaging. International Journal of Electrical and Computer Engineering (IJECE). 2016: 7(1).

[4] A Yudhana, Sunardi, S Saifullah. Perbandingan Segmentasi Pada Citra Asli Dan Citra Kompresi Wavelet Untuk Identifikasi Telur. Jurnal IImiah ILKOM. 2016; 8(3): 190-196.

[5] S Saifullah, Sunardi, A Yudhana, Analisis Perbandingan Pengolahan Citra Asli dan Hasil Croping Untuk Identifikasi Telur. Jurnal Teknik Informatika dan Sistem Informasi (JuTISI). 2016; 2(3): 341-350.

[6] Sunardi, A Yudhana, S Saifullah. Thermal Imaging Untuk Identifikasi Telur. Konferensi Nasional Ke-4 APPPTM Se-Indonesia 3. Teknologi, Hukum, Ekonomi dan Kesehatan 2016: 152-157.

[7] Trisnaningtyas, Puspa Rizky. Maimunah. Klasifikasi Mutu Telur Berdasarkan Kebersihan Kerabang Telur Menggunakan K-Nearest Neighbor. Konferensi Nasional Informatika (KNIF). 2015.

[8] Nurhayati, Oky Dwi. Sistem Analisis Tekstur Secara Statistik Orde Pertama Untuk Mengenali Jenis Telur Ayam Biasa dan Telur Ayam Omega-3. Jurnal Sistem Komputer. 2015; 5(2): 79-82

[9] Wijaya, Tria Adhi, Yudi. Prayudi. Implementasi Visi Komputer Dan Segmentasi Citra Untuk Klasifikasi Bobot Telur Ayam Ras. Seminar Nasional Aplikasi Teknologi Informasi. 2010, G1-G5.

[10] Khabibulloh, M Arif, Kusumawardhani, Apriani, Pratama, Detak Yan. Rancang Bangun Sistem Deteksi Embrio pada Telur Menggunakan Webcame. Jurnal Teknik Pomits. 2012; 1(1): 1-6. 
[11] Liu Hai-ling, Cai Jian-rong, Sun Li, Yuan Lei-ming, Liu Meng-lei. Research on the Discrimination of Hatching Eggs Activity Based on Thermal Imaging: A Food Nondestructive Testing Practice. International Journal of Smart Home. 2016; 10(2): 175-186.

[12] Chern-Sheng Lin, Po Ting Yeh, Der-Chin Chen, Yih-Chih Chiou, Chi-Hung Lee. The Identification and Filtering of Fertilized Eggs with a Thermal Imaging System. Computers and Electronics in Agriculture. 2013; 91: 94-105.

[13] L Liu, MO Ngadi. Detecting Fertility and Early Embryo Development of Chicken Eggs Using NearInfrared Hyperspectral Imaging. Springer, Food Bioprocess Technol. September 2013; 6: 2503-2513.

[14] TRIDINEWS. Penjelasan Fungsi dan Kegunaan dari Thermography. TriDiNews Update Information \& Sharing Knowledge. [Online] March 14, 2014. [Cited: September 1, 2016] http://www.news.tridinamika.com/

[15] Ruslianto, Ikhwan. Klasifikasi Telur Ayam Dan Telur Burung Puyuh Menggunakan Metode Connected Component Analysis. Jurnal IImiah SISFOTENIKA. 2013; 3(1): 41-50.

[16] Utami, Yustina Retno Arum. Pengenalan Telur Berdasarkan Karakteristik Warna Citra. Jurnal IImiah SINUS. 2009; 7(2): 1-14.

[17] Andono, Pulung Nurtantio. Konsep Pengolahan Citra Digital. Ed. 1. Yogyakarta: Andi: 2015.

[18] ChR Kumar. Enhancement of Image Sharpness with Bilateral and Adaptive Filter. International of Information and Education Technology. 2016; 6(1): 50-53.

[19] Ahmad U. Pengolahan Citra Digital \& Teknik Pemrogramannya, ed. 1, Yogyakarta: Graha IImu: 2005.

[20] Metode-algoritma.com. Perataan Ekualisasi Histogram Citra Digial. [Online] http://www.metodealgoritma.com/2015/07/metode-penyetaraan-histogram.html [Cited: September 3, 2016]

[21] A Singh, AS Bhide, P Singh. Text Extraction from Live Captured Image with Disversified Background using Edge Based \& K-means Clustering. International Journal in Engineering and Technology (IJIET). 2014; 3(3): 11-17.

[22] G Kaur, G Jindal. An Enhancement of Medical Images using Clasical Unsharp Mask Filter and Log Gabor Filter. International Journal of Innovatioan in Engineering and Technology (IJIET). 2013: 2(3): 45-47.

[23] Pramana CJ. Implementasi Metode Thresholding dan Metode Regionprops untuk Mendeteksi Marka Jalan Secara Live Video. Jurnal Universitas Dian Nuswantoro Semarang. 2014. 